\title{
PSYCHOLOGICAL HELP PREFERENCES TEST AND MOTIVATION OF UKRAINIAN VETERANS WITH THE USE OF DESIGNED TEST NAMED "10 Questions from Voronin" AND ZEIGARNIK EFFECT.
}

Mykola Voronin

Faculty of Social Sciences and Social

Technologies

Department of Psychology and

Pedagogics

National University of "Kyiv-Mohyla

Academy"

Kyiv, 04070, Ukraine voronin.mykola@ukma.edu.ua

\begin{abstract}
In the article a new test to investigate preferences of Ukrainian veterans in receiving psychological help was presented. It is designed by a war veteran and young scientist to be as simple as possible for veterans, so as not to consume their time. Named "10 Questions from Voronin" (10 QV). It is also designed to motivate veterans to think of help to prevent suicide by the means of the Zeigarnik effect. Pilot study based on 43 randomly tested Ukrainian war veterans is also introduced. Possible conclusions from this study are briefly presented and analysed.
\end{abstract}

Keywords: war veterans; psychological help preferences; Zeigarnik effect; pilot study; veterans motivation. 


\section{Introduction}

One of the serious problems that may lead to an increase in suicide rates in war veterans can be absence of their motivation to request psychological help by various means that are provided for them or absence of motivation to participate in rehabilitation activities. In the research by Michele R Spoont et al. (Spoont, M. R., Nelson, D. B., Murdoch, et al., 2014) it was found that after receiving a diagnosis of PTSD "Of veterans who were given a diagnosis of PTSD, only about two-thirds received some VA mental health care in the six months after the diagnosis. Only about half of those who received any mental health care received a minimally adequate treatment trial." It means that veterans were not engaged highly into the treatment. Reasons were not identified clearly. On the other hand, successful strategies leading to lower suicide rates were introduced for Ukraine particularly in 2002 (Rozanov, V. A., Mokhovikov, A. N., Stiliha, R. 2002) by Rozanov et al. However, the conclusion was made that "it is important to have constant contact with the targeted unit" while there is a need "to continue to implement this program of suicide prevention." Latest research in Germany (Niemeyer, H., Knaevelsrud, C., Schumacher et al. 2020) concerning "the efficacy of a therapist-guided internet-based cognitive-behavioral therapy" identified that "improvements were small" and dropout rate was "high", to be exact $32.3 \%$, which is close to results received among United States veterans by Michele R Spoont et al. (Spoont, M. R., Nelson, D. B., Murdoch, et al., 2014). But recent results received in Germany "demonstrate the need to identify factors influencing treatment engagement and efficacy in veterans." (Niemeyer, H., Knaevelsrud, C., Schumacher et al. 2020) These various research papers show that understanding reasons why veterans engage or do not engage in psychological help is very important, as well as understanding the most convenient ways of 
receiving it. For better understanding of the mentioned reasons a test named " 10 Questions from Voronin" (10 QV) was designed.

\section{The test named "10 Questions from Voronin" (10 QV)}

The $10 \mathrm{QV}$ test was designed by young scientist and veteran at the same time after some friends of his committed suicide upon being discharged from military service in Ukraine and participating in the recent/ongoing war against Russian Federation in the east of Ukraine. The author resigned from serving as a sniper at 73rd Ukrainian marine center of special operations. Actively participated in the war of Ukraine against Russian Federation from 2014 to 2021 in different roles: as an active military serviceman or volunteer combatant at volunteer battalion. Test author successfully finished a brief version of the Common Elements Treatment Approach (CETA) in Ukraine (Murray, L.K., Haroz, E.E., Doty, S.B. et al. 2018) and realised the need of understanding reasons why veterans do not engage in the different treatments and psychological programs designed for helping them. Or after engaging they drop out never to finish. For instance, MMPI-2 test can make a veteran seeking psychological help never return because it is too massive and complicated, although it can be effective for PTSD identification (Arbisi, P. A., Ben-Porath, Y. S., McNulty, J. 2006) it can not be used for identification of veterans preferences in receiving psychological help or in motivating them. So the new simple ten question test was designed to fit in one A4 standard page. The test was designed to fit in two pages A4. On the first page after disclaimer, gender and age request ten numbered questions were presented. First page contained:

The survey is conducted anonymously, as part of a study of veterans' motivation. 
Your gender

$\square$ Male.

$\square$ Female
Your age

I am years old.

1. Do veterans need psychological help?

$\square$ Yes. Help is needed

$\square$ No need

2. Do you think that psychological counseling should be mandatory after the end of the service, or should veterans seek psychological help on their own?

$\square$ Yes. All veterans must be consulted.

$\square$ No. Veterans must decide for themselves whether they need psychological help.

3. Do you think that it is a shame to go to a psychologist?

$\square$ Yes. It's a shame.

$\square$ No. This is normal practice.

4. Would you receive help from a psychologist after the service?

$\square$ Yes.There is nothing wrong with consulting a psychologist.

$\square$ No. I do not need psychological help.

5. Which psychologist do you think should consult after your service: civilian or military?

$\square$ Civilian.

$\square$ Military.

6. Is it enough to consult via the Internet or phone or do you think it is better to meet a psychologist in person after military service?

$\square$ enough online advice

$\square$ enough consultation by phone 
$\square$ it is better to meet in person

7. Would you like to get psychological help right now?

$\square$ Yes. I feel the need for psychological counseling.

$\square$ No. I don't need psychological help now.

8. Which psychologist do you think should consult during service: civilian or military?

$\square$ Civilian.

$\square$ Military.

9. Is it enough to consult via the Internet or phone or do you think it is better to meet a psychologist in person during military service?

$\square$ enough online advice

$\square$ enough consultation by phone

$\square$ it is better to meet in person

10. How can veterans be saved from suicide?

The survey was developed by Mykola Voronin as part of a study of veterans' motivation and the "Care Together" initiative to help veterans.

On the second page two unnumbered questions were asked:

What question do you remember the most?

Describe what you remember from it: 


\section{Description of the study}

10 QV consists of 10 numbered questions placed on one side of an A4 sheet and two additional questions placed on the other side of an A4 sheet. The study is anonymous and no personal data is taken into account. The only thing that is taken into account is age and gender of the respondent, the answer to these requests can be filled in before answering the numbered questions in the appropriate places on the first page of A4. The survey was conducted as follows: respondents were asked to fill in the first page, answer ten numbered questions, after finishing the first page it was proposed to turn the sheet and answer two additional questions and until the questions of the second page were answered it was not allowed to look back at the previous page. The $10 \mathrm{QV}$ test contains on the first page two unnumbered questions, where the respondent can indicate his age and gender. It also contains ten numbered questions, nine of these questions - test questions, tenth question was constructed without a proposed answer in order for respondents to face some difficulties while attempting to answer it (no room for answer was left). Theoretically the respondents were supposed to make a decision "leave it unanswered." This question is based on the Zeigarnik effect: the questions that were not answered are better remembered (Reeve J., Cole S.G., Olson, B.C. 1986). The tenth question is more motivational. Designed to motivate veterans think how to solve suicide problem and save more veteran lives. No instructions for answering questions were given. The respondent was supposed to complete this test intuitively.

Two questions from the second page, built to test the effectiveness of the Zeigarnik effect and identify questions that bother veterans most. Did you remember the relevant motivational questions, and how exactly did you 
remember them? At the bottom of each description page, the author and a short annotation with a description of the project and research are indicated in small print. The test is not subject to change at this time. Everything: questions, answer forms, placement on the page for unambiguous results remain unchanged.

\section{Pilot study based on 10 QV.}

In a pilot study of the $10 \mathrm{QV}$ test 43 randomly engaged veterans took part. 5 women and 38 men. 11 veterans of age 45 or older, 22 veterans between the ages of 30 and 45, 10 veterans under the age of 30 (Table 1).

\begin{tabular}{|l|l|l|l|}
\hline Age & 45 or older & $30-45$ & under 30 \\
\hline & 11 & 22 & 10 \\
\hline
\end{tabular}

Table 1. Veterans age distribution.

42 veterans answered positively on the first numbered question and only one veteran picked a negative answer (Table 2).

\begin{tabular}{|l|r|r|}
\hline 1. Do veterans need psychological help? & $\begin{array}{c}\text { Yes. Help is } \\
\text { needed. }\end{array}$ & No need. \\
\hline & 42 & 1 \\
\hline
\end{tabular}

Table 2. Answers to the first numbered question of $10 \mathrm{QV}$ distribution.

This can mean that almost all veterans who took part understand that psychological help is needed.

31 veteran of 43 preferred mandatory psychological help instead of seeking it on their own (Table 3). 


\begin{tabular}{|l|c|c|}
\hline 2. Do you think that psychological & & \\
counseling should be mandatory after & Yes. All & No. Veterans must decide \\
the end of the service, or should & veterans & for themselves whether \\
veterans seek psychological help on & must be & they need psychological \\
their own? & consulted. & help \\
\hline & 31 & \\
\hline
\end{tabular}

Table 3. Answers to the second numbered question of 10 QV distribution.

This question was asked not to legalise unethical mandatory treatment of veterans, but to understand how deeply veterans feel the need to obey orders as if they were inside a military structure where decisions are made by higher commanders. The distribution may show that 31 of 43 veterans still need an order to obey for psychological help receiving.

Answering the third numbered question "Do you think that it is a shame to go to a psychologist?" 40 of 43 veterans answered "No. This is normal practice." (Table 4)

\begin{tabular}{|l|l|l|}
\hline $\begin{array}{l}\text { 3. Do you think that it is a shame to go to a } \\
\text { psychologist? }\end{array}$ & $\begin{array}{l}\text { Yes. It's } \\
\text { a shame. }\end{array}$ & $\begin{array}{l}\text { No. This is normal } \\
\text { practice. }\end{array}$ \\
\hline & 3 & 40 \\
\hline
\end{tabular}

Table 4. Answers to the third numbered question of $10 \mathrm{QV}$ distribution.

This distribution may indicate that most veterans don't have issues with stigma and treat psychological help normally but more detailed analysis described in article "Stigma to psychological help among Ukrainian ATO/OJF veterans analysis: pilot study." (Voronin M. 2020) shows that stigma bothers Ukrainian veterans and it can be seen from answers like this (Picture 1): "That I answered it is not a shame." (Voronin M. 2020) 
Picture 1. Answer "Is it a shame to approach a psychologist" to the first question "What question do you remember the most?" and a proud answer "That I answered it is not a shame." for the second question "Describe what you remember from it:" in Ukrainian. (Voronin M. 2020)

The question number 4 "Would you receive help from a psychologist after the service?" distribution (Table 5) may show that $72 \%$ of veterans engaged in the pilot study would receive help from a psychologist after the service.

\begin{tabular}{|l|l|l|}
\hline $\begin{array}{l}\text { 4. Would you receive help } \\
\text { from a psychologist after } \\
\text { the service? }\end{array}$ & $\begin{array}{l}\text { Yes. There is nothing wrong } \\
\text { with consulting a } \\
\text { psychologist. }\end{array}$ & $\begin{array}{l}\text { No. I do not need } \\
\text { psychological } \\
\text { help. }\end{array}$ \\
\hline & 31 & 12 \\
\hline
\end{tabular}

Table 5. Answers to the fourth numbered question of $10 \mathrm{QV}$ distribution.

The question number 5 "Which psychologist do you think should consult after the service: civilian or military?" distribution (Table 6) may show that almost $60.5 \%$ of veterans engaged in the pilot study would prefer a military psychologist to a civil one after their service.

\begin{tabular}{|l|r|r|r|l|l|}
\hline $\begin{array}{l}\text { 5. Which psychologist do you } \\
\text { think should consult after the } \\
\text { service: civilian or military? }\end{array}$ & Civil & Military & Veteran & $\begin{array}{l}\text { No } \\
\text { answer }\end{array}$ & $\begin{array}{l}\text { Military } \\
\text { maybe }\end{array}$ \\
\hline & 16 & 26 & 1 & 1 & 1 \\
\hline
\end{tabular}


Table 6. Answers to the fifth numbered question of $10 \mathrm{QV}$ distribution.

The question number 6 "Is it enough to consult via the Internet or phone or do you think it is better to meet a psychologist in person after your service?" distribution (Table 7) may show that most veterans engaged in pilot study prefer personal meetings over online advice or consultation by phone after the service.

\begin{tabular}{|l|l|l|l|}
\hline $\begin{array}{l}\text { 6. Is it enough to consult via the Internet or } \\
\text { phone or do you think it is better to meet a } \\
\text { psychologist in person after the service? }\end{array}$ & $\begin{array}{l}\text { enough } \\
\text { online } \\
\text { advice }\end{array}$ & $\begin{array}{l}\text { enough } \\
\text { consultation } \\
\text { by phone }\end{array}$ & $\begin{array}{l}\text { it is better } \\
\text { to meet in } \\
\text { person }\end{array}$ \\
\hline & 1 & 1 & 43 \\
\hline
\end{tabular}

Table 7. Answers to the sixth numbered question of $10 \mathrm{QV}$ distribution.

The question number 7 "Would you like to get psychological help right now?" distribution (Table 8) may show that almost $67.5 \%$ of veterans engaged in pilot study think that they don't need psychological help when asked during 10 QV test.

\begin{tabular}{|l|l|l|l|}
\hline $\begin{array}{l}\text { 7. Would you like to get } \\
\text { psychological help right } \\
\text { now? }\end{array}$ & $\begin{array}{l}\text { Yes. I feel the need } \\
\text { for psychological } \\
\text { counseling. }\end{array}$ & $\begin{array}{l}\text { No. I don't need } \\
\text { psychological } \\
\text { help now. }\end{array}$ & $\begin{array}{l}\text { I am veteran } \\
\text { psychologist }\end{array}$ \\
\hline & 14 & 29 & 1 \\
\hline
\end{tabular}

Table 8. Answers to the seventh numbered question of $10 \mathrm{QV}$ distribution.

One veteran did not pick suggested answers and added his own answer "I am veteran psychologist" (Picture 2).

7. Ви б хотіли отримати психологічну допомогу прямо зараз?

口 Так. Я відчуваю потребу у психологічній консультації.

๑ Ні. Мені психологічна допомога зараз не потрібна.

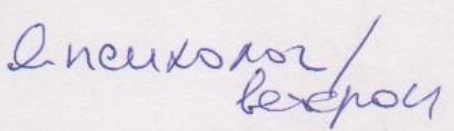

Picture 2. Answer "I am veteran psychologist" to the seventh numbered question of $10 \mathrm{QV}$. 
The question number 8 "Which psychologist do you think should consult during the service: civilian or military?" distribution (Table 9) may show that almost $74.5 \%$ of veterans engaged in pilot study would prefer a military psychologist to a civil one during their service, which is 14 percent more than the same question after the service (Table 6).

\begin{tabular}{|l|r|l|}
\hline $\begin{array}{l}\text { 8. Which psychologist do you think should be } \\
\text { consulted during the service: civilian or military? }\end{array}$ & Civil & Military \\
\hline & 11 & 32 \\
\hline
\end{tabular}

Table 9. Answers to the eighth numbered question of $10 \mathrm{QV}$ distribution.

The question number 9 "Is it enough to consult via the Internet or phone or do you think it is better to meet a psychologist in person during the service?" distribution (Table 10) may show that most veterans engaged in the pilot study still prefer personal meetings over online advice or consultation by phone during the service, but more veterans allow other than personal meeting choices (compared to Table 7).

\begin{tabular}{|c|c|c|c|}
\hline $\begin{array}{l}\text { 9. Is it enough to consult via the Internet } \\
\text { or phone or do you think it is better to } \\
\text { meet a psychologist in person during the } \\
\text { service? }\end{array}$ & $\begin{array}{l}\text { enough } \\
\text { online } \\
\text { advice }\end{array}$ & $\begin{array}{l}\text { enough } \\
\text { consultation } \\
\text { by phone }\end{array}$ & $\begin{array}{l}\text { it is better } \\
\text { to meet in } \\
\text { person }\end{array}$ \\
\hline & & & \\
\hline
\end{tabular}

Table 10. Answers to the ninth numbered question of $10 \mathrm{QV}$ distribution.

One of the most interesting questions "How can veterans be saved from suicide?", which had no proposed answers, was left unanswered in 24 cases and 19 veterans decided to give their own answers (Table 11) without paying attention to the obstacles that were made by $10 \mathrm{QV}$ author (no space for answer was left). 


\begin{tabular}{|l|r|r|}
\hline 10. How can veterans be saved from suicide? & No answer & Answered \\
\hline & 24 & 19 \\
\hline
\end{tabular}

Table 11. Answers to the tenth numbered question of $10 \mathrm{QV}$ distribution.

So the Zeigarnik effect can be evaluated from 24 participants that did not answer the tenth question. And from the 43 veterans only 11 veterans picked the last question as the one that they remembered most and only 3 of them did not answer the tenth question (Voronin M. 2021).

The most popular question veterans remembered was the tenth (11 veterans), in second place was the third question (8 veterans), third popular was the fifth question (5 veterans), in fourth place was question number one (4 veterans), fifth place was shared by questions $6,7,8,9$ (three veterans each), sixth place was question number 2 (with two veterans) and the least popular was question number 4, twelve veterans did not answer which question they remembered most (Table 12). One can see that the most preferable answer for veterans on the second page of $10 \mathrm{QV}$ was "No answer" (Table 12). Which can mean that 12 veterans of 43 were not motivated enough to finish the test.

\begin{tabular}{|l|r|r|r|r|r|r|r|r|r|r|l|}
\hline $\begin{array}{l}\text { What question do you remember } \\
\text { the most? }\end{array}$ & 1 & 2 & 3 & 4 & 5 & 6 & 7 & 8 & 9 & 10 & $\begin{array}{l}\text { No } \\
\text { answer }\end{array}$ \\
\hline & 4 & 2 & 8 & 1 & 5 & 3 & 3 & 3 & 3 & 11 & 12 \\
\hline
\end{tabular}

Table 12. Questions remembered most among veterans distribution.

Raw data of this pilot study in Ukrainian language can be found at the repository (Voronin M. 2021).

\section{Conclusion.}


After the pilot study was completed we can see that the 10 QV simple test may give a massive amount of information to researchers about veterans and their preferences. Although it is not very easy to analyse as precious information can be found on the fields literally, some useful conclusions can be taken from it. For instance, it is clear that veterans engaged in this pilot study prefer personal meetings with psychologists during and after service, but during service they can take online advice or phone consultation as an option more preferably than after the service. They have more trust in military psychologists than in civil ones, and military psychologists are more preferable than civil ones during the service. Due to complexity of analysis it is not recommended to use $10 \mathrm{QV}$ for big scale surveys, but for more deep small groups of veterans understanding it can be used.

\section{References}

Arbisi, P. A., Ben-Porath, Y. S., \& McNulty, J. (2006). The ability of the MMPI-2 to detect feigned PTSD within the context of compensation seeking. Psychological Services, 3(4), 249-261. https://doi.org/10.1037/1541-1559.3.4.249

Murray, L.K., Haroz, E.E., Doty, S.B. et al. (2018) Testing the effectiveness and implementation of a brief version of the Common Elements Treatment Approach (CETA) in Ukraine: a study protocol for a randomized controlled trial. Trials 19, 418 . https://doi.org/10.1186/s13063-018-2752-y

Niemeyer, H., Knaevelsrud, C., Schumacher, S., Engel, S., Kuester, A., Burchert, S., Muschalla, B., Weiss, D., Spies, J., Rau, H., \& Willmund, G. D. (2020). Evaluation of an internet-based intervention for service members of the German armed forces with deployment-related 
posttraumatic stress symptoms. BMC psychiatry, 20(1), 205. https://doi.org/10.1186/s12888-020-02595-Z

Reeve J., Cole S.G., Olson, B.C. (1986) The Zeigarnik effect and intrinsic motivation: Are they the same? Motiv Emot 10, 233-245 . https://doi.org/10.1007/BF00992318

Rozanov, V. A., Mokhovikov, A. N., Stiliha, R. (2002). Successful model of suicide prevention in the Ukraine military environment. Crisis: The Journal of Crisis Intervention and Suicide Prevention, 23(4), 171-177. https://doi.org/10.1027/0227-5910.23.4.171

Spoont, M. R., Nelson, D. B., Murdoch, M., Rector, T., Sayer, N. A., Nugent, S., \& Westermeyer, J. (2014). Impact of treatment beliefs and social network encouragement on initiation of care by VA service users with PTSD. Psychiatric services (Washington, D.C.), 65(5), 654-662. https://doi.org/10.1176/appi.ps.201200324

Voronin M. (2021) Private repository. Retrieved from:

https://drive.google.com/drive/folders/1RreELmGzmLSnkz 1Mexymir-knc -jKu7?usp=sharing

Voronin M. (2020) Stigma to psychological help among Ukrainian ATO/OJF veterans analysis: pilot study. EUROPEAN HUMANITIES STUDIES: State and Society, 22(4), 4-14. 